\title{
Chemical Composition and Lipid Fraction Characteristics of Aleppo Pine (Pinus halepensis Mill.) Seeds Cultivated in Tunisia
}

\author{
S. Cheikh-Rouhou, ${ }^{1}$ B. Hentati, ${ }^{2}$ S. Besbes, ${ }^{1, *}$ C. Blecker,${ }^{3}$ C. Deroanne ${ }^{3}$ and H. Attia ${ }^{1}$ \\ 'Unité Analyses Alimentaires, Ecole Nationale d'Ingénieurs de Sfax, Route de Soukra 3038 Sfax, Tunisia \\ ${ }^{2}$ Unité de Biotechnologie et Pathologie, Institut Supérieur de Biotechnologie de Sfax, Route de Soukra 3038 Sfax, \\ Tunisia \\ ${ }^{3}$ Unité de Technologie des Industries Agro-alimentaires, Faculté Universitaire des Sciences Agronomiques de \\ Gembloux, passage des Déportés 2, 5030 Gembloux, Belgium
}

\begin{abstract}
The proximate composition of Aleppo pine (Pinus halepensis Mill.) seeds cultivated in Bizerta (Tunisia) were investigated for their fatty acid composition, and their thermal and physical properties of lipid fraction. The proximate analysis of pine seeds showed the following composition (on a dry-weight basis): protein $22.7 \%$, oil $43.3 \%$, ash $8.3 \%$ and total carbohydrate $25.7 \%$. Potassium, magnesium and calcium were the predominant mineral elements present in the seeds and reached, together, about $1 \%$. Oleic and linoleic acids were the major unsaturated fatty acids ( 27.3 and $48.8 \%$, respectively), while the main saturated one was palmitic acid $(8.75 \%)$. Myristic, myristoleic, palmitoleic, margaric, margaroleic, stearic, linolenic, arachidic, eicosenoic, eicosadienoic eicosatrienoic behenic and lignoceric acids were also detected. Thermal profile of Pinus halepensis Mill. seed oil, determined by its DSC melting curve, showed that the entire liquefaction of the Aleppo pine seed oil occurs at $-8^{\circ} \mathrm{C}$. CieLab colour parameters $\left(L^{*}, a^{*}, b^{*}\right)$, oxidative stability by Rancimat test and viscosity were also determined. Physicochemical properties of the oil include: saponification number 190, peroxide value 3.18, iodine index 117 , and a low acidity of $0.61 \%$. Results suggested that the production of oil from Pinus halepensis seeds could provide a potential use in food, pharmaceutical, cosmetics and other non-food industries.
\end{abstract}

Key Words: Pinus halepensis Mill. seeds, oil, fatty acids, thermal profile

\section{INTRODUCTION}

Aleppó pine (Pinus halepensis), described by Miller in 1768, is a circummediterranean species (Nahal, 1986). This woody and perennial pine tree, cultivated in the Mediterranean area is useful for reforestation (Le Thiec and Manninen, 2003). Pinus halepensis species belonging to the Pinaceae family and is the most widely distributed pine in this region. where it covers more than $25,000 \mathrm{~km}^{2}$ (Maestre et al., 2003). The main Aleppo pine forests are found in Spain, France

*To whom correspondence should be sent

(e-mail: besbes.s@voila.fr).

Received 9 November 2005; revised 23 January 2006.

Food Sci Tech Int 2006; 15(5):407-416

(C) 2006 SA GE Publications

ISSN: $1082-0132$

DOI: $10.1177 / 1082013206069910$ and North Africa (Raeda and Arianoutsou, 2000) especially in Algeria and Tunisia where they constitute a clump (Nahal, 1986). In Tunisia, Aleppo pine covers near 300,000 ha from the mountains to the south of Mejerda and to the west of Zaghouan, to the central region of Tunisia (Bizerta, Ben Arous, Nabeul. Zaghouan, Beja, Jendouba, El Kef, Kairouan and Kasserine). Pinus species are essentially grouped as soft pines (haploxylon) and hard pines (diploxylon). Pinus halepensis Mill. belongs to diploxylon pine groups, which produce the most commercialised pine seeds in the world. In fact, these seeds, lodged in large cones, are highly nutritious and very appreciated by consumers.

Aleppo pine seeds are traditionally used throughout Tunisia, and other Islamic countries, for preparing a sweet pudding of ground pine seeds, called 'AssidaZgougou'. Recently, it has also been employed as an ingredient in ice-creams and candies. A few works have been published on the Tunisian Aleppo pine 
seeds (Nasri and Triki, 2004) which focus on the fatty acid composition, the unsaponifiable fraction and the phenolic compounds of the corresponding oil, however not on their detailed composition and physicochemical properties.

The aim of this work was to study the chemical composition of Pinus halepensis seeds cultivated in Tunisia and to determine the fatty acid composition and physico-chemical properties of their lipid fraction.

\section{MATERIALS AND METHODS}

\section{Materials}

Seeds

Aleppo pine seeds (Pinus halepensis Mill.) were purchased $(20 \mathrm{~kg})$ from a herbal market in Bizerta (Tunisia), where they were harvested. Seeds were directly stored at $15^{\circ} \mathrm{C}$ for a maximum of 3 days and then cleaned manually to remove foreign matter. Seed samples were separately milled in a heavy-duty grinder for $4 \mathrm{~min}$ to pass $1-2 \mathrm{~mm}$ screens and then fractioned into 40 powdered samples $(500 \mathrm{~g})$ which are preserved in hermetic bags at $-20^{\circ} \mathrm{C}$ until analysis.

\section{Methods}

\section{Oil extraction and preservation}

Aleppo pine seeds $(50 \mathrm{~g})$ were placed in a dark flask (capacity $=1 \mathrm{~L}$ ) and homogenised with $250 \mathrm{~mL}$ of hexane. The mixture was moved for $4 \mathrm{~h}$ in a shaker (Selecta, Spain) at $180 \mathrm{U} / \mathrm{min}$, and then centrifuged for $15 \mathrm{~min}$ at $1,000 \times \mathrm{g}$. The extraction was conducted at $24 \pm 1{ }^{\circ} \mathrm{C}$. The supernatent was filtered through a Whatman No. 2 filtering paper. The extraction procedure was repeated twice and the collected solvent was removed using a rotary evaporator at $40^{\circ} \mathrm{C}$. The seed oil obtained was finally drained under a stream of nitrogen and then stored in a freezer $\left(-20^{\circ} \mathrm{C}\right)$ for subsequent physico-chemical analyses.

\section{Analytical Methods}

All analytical determinations were performed at least in triplicate. Values were expressed as the mean \pm standard deviation.

\section{Chemical Analysis of Powdered Seeds}

The dry matter was determined according to the Association of Official Analytical Chemists (AOAC, 1990).

Oil was extracted from $15 \mathrm{~g}$ of Aleppo pine seed powder in a Soxhlet extractor for $8 \mathrm{~h}$ using hexane as a solvent at $45^{\circ} \mathrm{C}$. The result was expressed as the percentage of lipids in the dry matter of seed powder.

Total protein was determined by the Kjeldahl method. Protein was calculated using a nitrogen conversion factor of 5.30 for pine nut seeds (Greenfield and Southgate, 1992; Nergiz and Dönmez, 2004).

To remove organic matter, about $0.5 \mathrm{~g}$ of powdered seed samples were incinerated in the muffle furnace at $550^{\circ} \mathrm{C}$ for about $12 \mathrm{~h}$. The ashes were dissolved in $\mathrm{HNO}_{3}$ (Larrauri et al., 1996) and the mineral constituents ( $\mathrm{Ca}, \mathrm{Na}, \mathrm{K}, \mathrm{Mg}, \mathrm{Fe}, \mathrm{Zn}, \mathrm{Cu}$ and $\mathrm{Mn}$ ) were determined using an atomic absorption spectrophotometer (Hitachi Z 6100, Japan). The phosphorus content was analysed by the phosphomolybdovanadate method (AOAC, 1990). The total ash was expressed as a percentage of dry matter.

The carbohydrate content was estimated by difference of mean values and dry matter content.

Analysis of Oil Extract

AOCS official methods (American Oil Chemists' Society, AOCS, 1997) were used to evaluate the peroxide, iodine, saponification and acidity values (methods number Cd 8-53, Cd 3d-63, Cd 3-25 and Cd 3d-63, respectively). Determination of refractive index (at $20^{\circ} \mathrm{C}$ ) was determined with a refractometer (Abbe-Zeiss).

$K_{232}$ and $K_{270}$ extinction coefficients were calculated from absorption at 232 and $270 \mathrm{~nm}$, respectively, with a UV spectrophotometer (Secoman, Anthelie $70 \mathrm{MI}$ 0291, No. 344, France) using a $1 \%$ solution of oil in cyclohexane and a path length of $1 \mathrm{~cm}$.

Chlorophyll content was determined by spectrophotometry following the methodology described by Mínguez et al. (1991).

Total phenols, expressed as gallic acid ( $\mathrm{mg} / \mathrm{kg}$ of oil) were determined colorimetrically at $725 \mathrm{~nm}$ using Folin-Ciocalteau reagent as previously done by Gutfinger (1981) on virgin olive oil.

Viscosity was measured with a Stress Tech Rheologica Rheometer (Rheologica Instruments $A B$, Lund, Sweden). Measurements were performed at $25^{\circ} \mathrm{C}$ with a steel cone-plate $(\mathrm{C} 40 / 4)$ under a constant shear rate of $100 / \mathrm{s}$.

Absorbance of oil solutions in hexane was measured with a UV-240 spectrophotometer (Shimadzu-Corporation, Kyoto, Japan).

The CieLab coordinates $\left(L^{*}, a^{*}, b^{*}\right)$ were measured with a spectrophotometer MS/Y-2500 (Hunterlab, Inc., Reston, VA, USA), calibrated with a white tile (Besbes et al., 2004a). Absorbance of oil solutions in hexane was measured with a spectrophotometer UV-240 (Shimadzu Corporation, Kyoto, Japan) with light of wavelengths between 205 and $800 \mathrm{~nm}$ (Besbes et al., 2004a).

Oxidation stability was evaluated by measuring the oxidation induction time, with the use of the Rancimat 679 apparatus (Metrohm AG, Herison, Switzerland). A flow of air $(15 \mathrm{~L} / \mathrm{h})$ was bubbled through the oil 
Table 1. Chemical composition of Pinus halepensis and Pinus pinea seeds.

\begin{tabular}{ccc}
\hline Composition & Pinus halepensis seeds (mean $\pm \mathrm{SD}, \mathrm{n}=3$ ) & Pinus pinea seeds $^{1}$ \\
\hline Dry matter $(\%)$ & $94.8 \pm 0.1$ & 94.9 \\
Oil $(\mathrm{g} / 100 \mathrm{~g})$ & $43.3 \pm 0.5$ & 44.9 \\
Crude protein $(\mathrm{g} / 100 \mathrm{~g})$ & $22.7 \pm 0.5$ & 31.6 \\
Ash $(\mathrm{g} / 100 \mathrm{~g})$ & $8.3 \pm 0.1$ & 4.5 \\
Total carbohydrate $(\mathrm{g} / 100 \mathrm{~g})$ & $25.7 \pm 0.2$ & 13.9 \\
\hline
\end{tabular}

'Nergiz and Dönmez (2004).

Table 2. Minerals of Pinus halepensis seeds compared to other seeds.

\begin{tabular}{|c|c|c|c|c|}
\hline \multirow[b]{2}{*}{ Minerals } & \multicolumn{4}{|c|}{ Mineral content of seeds $(\mathrm{mg} / \mathrm{kg})$} \\
\hline & $\begin{array}{l}\text { Pinus halepensis } \\
\text { (mean } \pm S D, n=3 \text { ) }\end{array}$ & Xylopia aethiopica ${ }^{1}$ & Pinus pinea ${ }^{2}$ & Deglet Nour ${ }^{3}$ \\
\hline Potassium & $6171 \pm 12.0$ & 8676.3 & 7130 & 2290 \\
\hline Magnesium & $3303 \pm 9.8$ & 1266.5 & 3250 & 517 \\
\hline Calcium & $1167 \pm 4.9$ & 13020.9 & 138 & 388 \\
\hline Phosphorus & $568 \pm 0.8$ & 1840.0 & 5120 & 683 \\
\hline Sodium & $69.6 \pm 0.1$ & 68.5 & 117 & 104 \\
\hline Iron & $271 \pm 1.8$ & 203.5 & 102 & 23 \\
\hline Copper & $22.5 \pm 0.1$ & 43.5 & 15 & Nd \\
\hline Zinc & $134.9 \pm 0.4$ & 38.5 & 64 & $\mathrm{Nd}$ \\
\hline Manganese & $51.3 \pm 0.1$ & Nd & 69 & $\mathrm{Nd}$ \\
\hline
\end{tabular}

'Barminas et al. (1999); ${ }^{2}$ Nergiz and Dönmez (2004); ${ }^{3}$ Besbes et al. (2004a). Nd: not determined.

$(2.5 \mathrm{~g})$ heated at $100^{\circ} \mathrm{C}$ and the volatile degradation products were trapped in distilled water, increasing the water conductivity. The induction time was defined as the time necessary to reach the inflection point of the conductivity curve (Halbault et al., 1997).

Fatty acid composition was analysed by gas-liquid chromatography after derivatisation to fatty acid methyl esters (FAMEs) with $2 \mathrm{M} \mathrm{KOH}$ in methanol at room temperature according to the IUPAC standard method (IUPAC, 1992). Analyses of FAMEs were carried out with a Hewlett-Packard 5890 Series II gas chromatograph (H. P. Co., Amsterdam, The Netherlands) equipped with a hydrogen flame ionisation detector and a capillary column: HP Inovax crosslinked PEG $(30 \mathrm{~m} \times 0.32 \mathrm{~mm} \times 0.25 \mu \mathrm{m}$ film $)$. The column temperature was programmed from 180 to $240^{\circ} \mathrm{C}$ at $5^{\circ} \mathrm{C} / \mathrm{min}$ and the injector and detector temperatures were set at $250^{\circ} \mathrm{C}$. Identification and quantification of FAMEs was accomplished by comparing the retention times of peaks with those of pure standards purchased from Sigma and analysed under the same conditions. The results were expressed as a percentage of individual fatty acids in the lipid fraction.

Thermal characteristics of Pinus halepensis seed oil was performed using a modulated differential scanning calorimeter (DSC 2920 Modulated DSC-TA Instruments, Newcastle, DE, USA). Oil samples $(2 \pm 0.10 \mathrm{mg})$ were weighed directly in a DSC-pan (SFI-Aluminium, TA Instrument T11024). The samples were quickly cooled to $-50^{\circ} \mathrm{C}$ with a speed of $15^{\circ} \mathrm{C} / \mathrm{min}$, maintained at this temperature for $15 \mathrm{~min}$ and heated to $90^{\circ} \mathrm{C}$ with a heating speed of $15^{\circ} \mathrm{C} / \mathrm{min}$. The same operation (cooling and heating) was repeated and the DSC thermographs were recorded during the second melting. An empty DSC-pan was used as reference. The instrument was calibrated for temperature and heat flow using eicosane $\left(\mathrm{Tp}=36.80^{\circ} \mathrm{C}, \mathrm{H}=247.70 \mathrm{~J} / \mathrm{g}\right)$ and dodecane $\left(\mathrm{Tp}=-9.65^{\circ} \mathrm{C}, \mathrm{H}=216.73 \mathrm{~J} / \mathrm{g}\right)$. Solid fat content was determined from the DSC melting curve according to Deroanne (1977).

\section{RESULTS AND DISCUSSION}

\section{Chemical Composition of Aleppo Pine Seeds}

The average composition of Pinus halepensis seeds is shown in Table 1 . The moisture content and the amount of oil were $5.15 \%$ and $3.34 \%$, respectively. Quite similar results were reported by Nergiz and Dönmez (2004) for Pinus pinea seed oil. Wolff and Bayard (1995) reported that the oil content of some varieties of pine seeds varied from 31 to $68 \%$, however Nasri and Triki (2004) found that Tunisian Pinus halepensis Mill. contained $34.63 \%$, an amount lower than our results for the same species. In general, pine seeds are rich in oils, their content varies due to differences in species and environmental factors (Nergiz and Dönmez, 2004). The average protein content of the seeds $(22.66 \%)$ was lower than that reported for Pinus pinea by those authors.

Aleppo pine seeds mineral profile was compared to those of other seeds such as Pinus pinea, Xylopia 
aethiopica and Phoenix dactylifera L. (Table 2). Pinus halepensis seeds contained significant amounts of important mineral elements (Table 2, macro and micro constituents). Potassium was the most abundant element in the Pinus halepensis seeds, followed by magnesium and calcium. The other elements, in descending order by quantity, were $\mathrm{P}, \mathrm{Fe}, \mathrm{Zn}, \mathrm{Na}, \mathrm{Mn}$ and $\mathrm{Cu}$. Pinus halepensis seeds seemed to have lower amounts of phosphorus and sodium than those reported for Deglet Nour and Pinus pinea seeds, also calcium and copper were lower than those for Xylopia aethiopica, while magnesium, iron and zinc were detected to be the highest, compared with those reported for all the oil seeds studied. Pinus halepensis seeds provide appreciable amounts of microelements ( $\mathrm{Mn}, \mathrm{Zn}, \mathrm{Cu}$ and $\mathrm{Fe}$ ) from a nutritional point of view. They could significantly contribute to the daily requirements of all the elements studied.

\section{Profile of Aleppo Pine Seed Oil}

As previously studied, the lipid fraction was found to be the most abundant in Pinus halepensis seeds. Consequently, we were interested in determining fatty acid composition, and thermal and physical profiles of Aleppo pine seed oil.

\section{Fatty Acid Composition}

Essential fatty acids and their long-chain derivatives are important structural elements of cell membranes and are essential for the formation of new tissues (McKevith, 2005).
Fatty acid composition of Pinus halepensis seed oil (Table 3) showed that linoleic and oleic acids account for more than $76 \%$ of the total fatty acids. Pinus halepensis seed oil is rich in unsaturated fatty acids. This result was in accordance with those reported for Pinus pinea seed oil (Nergiz and Dönmez, 2004; Nasri et al., 2005). Previous studies showed that the oils of Pinus varieties contained oleic and linoleic acids at relatively high levels (Sagrero-Nieves, 1992; Wolff and Marpeau, 1997) in agreement with our results. In this study, saturated fatty acids (SAFA) accounted for $16.8 \%$ of total fatty acids. Among them, the main saturated acids were palmitic, stearic and behenic, with minute amounts of arachidic, lignoceric, myristic and margaric. The high polyunsaturated fatty acids (PUFA) to SAFA ratio of $3: 1$ is attributed to a high level of PUFA. This is a health benefit, as consumption of diets high in PUFA have been shown to have an inverse correlation to coronary heart disease (Thompson et al., 1993). Therefore, the consumption of these seeds in sufficient amounts could contribute positively to human health.

The $\omega 6 / \omega 3$ ratio is very important in terms of human nutrition. An estimate of the ratio in our diet 100 years ago was between 3:1 and 5:1 (Guilliams, 2000) and for the ideal daily consumption varies from $2: 1$ to $4: 1$ (Eramus, 1993). Pinus halepensis seed oil showed a lower $\omega 6 / \omega 3$ ratio compared to Pinus pinea seed oil $(\sim 10: 1$ as against $\sim 70: 1)$. This ratio is very variable in usual vegetable oils used in human food, such as olive oil, sunflower oil, soybean oil, palm oil and corn oil $(13: 1 ; 199: 1 ; 7: 1 ; 45: 1$ and 82:1, respectively; Guilliams, 2000).

Table 3. Fatty acid composition of Pinus halepensis seed oil.*

\begin{tabular}{|c|c|c|}
\hline Fatty Acid (FA) & $\begin{array}{c}\text { Pinus halepensis seed oil } \\
(\mathrm{g} / 100 \mathrm{~g} \text { of total FA, mean } \pm \mathrm{SD}, \mathrm{n}=3 \text { ) }\end{array}$ & Pinus pinea seed oil' \\
\hline Myristic $\mathrm{C}_{14: 0}$ & $0.09 \pm 0.02$ & $0.05 \pm 0.004$ \\
\hline Myristoleic $C_{14: 1}$ & $0.08 \pm 0.01$ & $\mathrm{Nd}$ \\
\hline Palmitic $C_{16: 0}$ & $8.75 \pm 0.51$ & $6.49 \pm 0.078$ \\
\hline Palmitoleic $C_{161}$ & $0.22 \pm 0.11$ & $0.224 \pm 0.03$ \\
\hline Margaric $\mathrm{C}_{17.0}$ & $0.08 \pm 0.01$ & $\mathrm{Tr}$ \\
\hline Margaroleic $\mathrm{C}_{17: 1}$ & $\mathrm{Tr}$ & $\mathrm{Nd}$ \\
\hline Stearic $\mathrm{C}_{18: 0}$ & $4.32 \pm 0.18$ & $3.47 \pm 0.1$ \\
\hline Oleic $\mathrm{C}_{18: 1}$ & $27.3 \pm 1.7$ & $38.6 \pm 0.6$ \\
\hline Linoleic $\mathrm{C}_{18: 2}$ & $48.8 \pm 2.4$ & $47.6 \pm 0.3$ \\
\hline Linolenic $C_{18: 3}$ & $4.86 \pm 0.36$ & $0.68 \pm 0.001$ \\
\hline Arachidic $C_{20: 0}$ & $0.62 \pm 0.01$ & $0.54 \pm 0.03$ \\
\hline Eicosenoic $\mathrm{C}_{20: 1}$ & $0.83 \pm 0.06$ & $0.79 \pm 0.06$ \\
\hline Eicosadienoic $\mathrm{C}_{20.2}$ & $0.42 \pm 0.05$ & $\mathrm{Nd}$ \\
\hline Eicosatrienoic $\mathrm{C}_{20: 3}$ & $0.49 \pm 0.03$ & $\mathrm{Nd}$ \\
\hline Behenic $\mathrm{C}_{22: 0}$ & $2.89 \pm 0.23$ & $0.13 \pm 0.01$ \\
\hline Lignoceric $\mathrm{C}_{24: 0}$ & $0.18 \pm 0.11$ & $3.02 \pm 0.02$ \\
\hline SAFA & $16.8 \pm 1.3$ & $13.7 \pm 0.2$ \\
\hline MUFA & $28.4 \pm 2.3$ & $39.6 \pm 0.7$ \\
\hline PUFA & $54.2 \pm 3.4$ & $48.3 \pm 0.3$ \\
\hline
\end{tabular}

'Nergiz and Dönmez (2004). SAFA: saturated fatty acids; MUFA: monounsaturated fatty acids; PUFA: polyunsaturated fatty acids; Tr: trace ( $\leq 0.05 \%)$; Nd: Not detected. 


\section{Thermal Properties}

Differential scanning calorimetry (DSC) is a fast and direct way to assess the quality of oil (Gloria and Aguilera, 1998). Any endothermic or exothermic event is registered as a peak in the chart, and its area is proportional to the enthalpy gained or lost, respectively. Pinus halepensis seed oil exhibited a thermogram with three thermal structural transitions between -39.83 and $-12.05^{\circ} \mathrm{C}$, indicative of crystalline melting (Figure 1 ). The obtained peaks were asymmetric and may indicate the presence of three components, having different weights. The first small endothermic peak at $-39.83^{\circ} \mathrm{C}$ may represent the melting of the unstable $\alpha$ crystal form, followed by the crystallisation of the unstable $\beta$ ' form and the last one may correspond to the more stable $\beta$ form. This hypothesis should be supported later by the X-ray diffraction method to identify the crystalline forms. The fact that thermograms seemed to correspond to a number of compounds higher than those clearly shown, suggests the presence of mixed glyceride groups with different melting points in the used conditions (Herrera and Anon, 1991). After total solidification, mixed glyceride crystals should be formed by intersolubility. They are associated in different crystalline groups with different

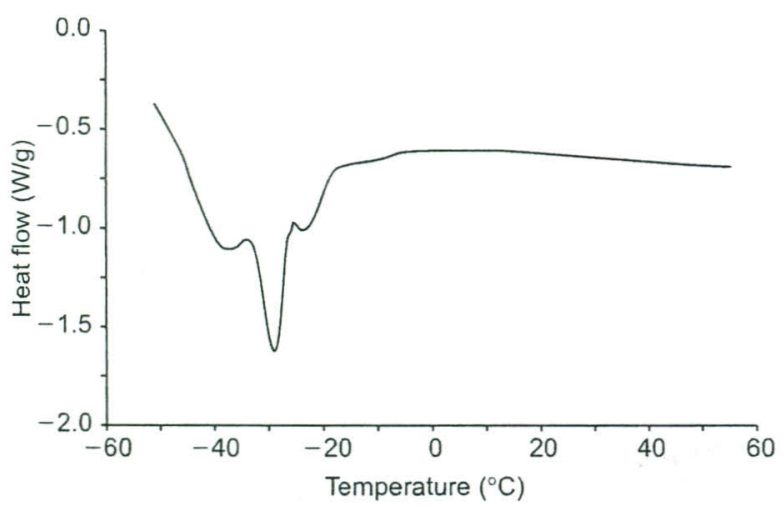

Figure 1. Melting thermogram of Aleppo pine seed oil.

Table 4. Thermal parameters, from DSC melting curves, of Pinus halepensis seed oil.

\begin{tabular}{cc}
\hline Parameter & $\begin{array}{c}\text { Pinus halepensis } \\
\text { (mean } \pm \mathrm{SD}, \mathrm{n}=3 \text { ) }\end{array}$ \\
\hline Peak transition temperatures $\left({ }^{\circ} \mathrm{C}\right)$ & \\
$\mathrm{T} 1$ & $-39.83 \pm 0.18$ \\
$\mathrm{~T} 2$ & $-29.37 \pm 0.18$ \\
$\mathrm{~T} 3$ & $-23.36 \pm 0.31$ \\
& \\
Onset temperature $\left({ }^{\circ} \mathrm{C}\right)$ & $-42.3 \pm 1.3$ \\
Peak temperature $\left({ }^{\circ} \mathrm{C}\right)$ & $-29.37 \pm 0.18$ \\
Total melting enthalpy $(\mathrm{J} / \mathrm{g})$ & $52.5 \pm 3.3$ \\
\hline
\end{tabular}

melting points. Pinus halepensis seed oil exhibited a melting peak $\left(-29.37^{\circ} \mathrm{C}\right)$, a melting enthalpy $(52.5 \mathrm{~J} / \mathrm{g})$ and an onset temperature $\left(-42.3^{\circ} \mathrm{C}\right.$, Table 4$)$, values lower than those reported by Besbes et al. (2004a) for date seed oils. This was due to the higher PUFA in Aleppo pine seed oil (54.2 as against 14.0 for Aleppo pine and Deglet Nour seed oils, respectively).

Solid fat content decreased when temperature increased (Figure 2) and remained constant for temperatures above $-8^{\circ} \mathrm{C}$, that corresponded to the entire liquefaction of Aleppo pine seed oil. Liquefation of Deglet Nour seed oil (Besbes et al., 2004a) began at $15^{\circ} \mathrm{C}$. This can be explained by the fact that Deglet Nour seed oil had a higher SAFA content than the Aleppo pine seed oil (44.3 as against 16.8, respectively).

\section{Colour}

Aleppo pine seed oil showed lower $L^{*}, a^{*}$ and $b^{*}$ values than those reported for Deglet Nour seed oil (57.31, -1.82 and 30 as against $66,-0.4$ and 55 , for Aleppo pine and Deglet Nour seed oils, respectively; Besbes et al., 2004a). This means that Pinus halepensis seed oil was slightly darker than Deglet Nour seed oil. Such a colour seems to attract consumers (Hsu and Chung, 1998). The CieLab $\left(L^{*}, a^{*}, b^{*}\right)$ values of other vegetable oils, such as palm, soybean, sunflower, olive and corn ranged from, 63.4 to $69.5,3.8$ to 4.4 and 9.2 to 10.4, respectively (Hsu and $\mathrm{Yu}, 2002$ ). Pinus halepensis seed oil $b^{*}$ value was higher than those of other vegetable oils. Pinus halepensis seed oil was more yellowcoloured than vegetable oils studied by $\mathrm{Hsu}$ and $\mathrm{Yu}$ (2002). This may suggest the presence of more yellow pigments (carotenoids) in Pinus halepensis seed oil. Aleppo pine seed oil showed another colour particularity: Hunter $a^{*}$ negative value $(-1.82)$ was markedly lower than the Hunter $a^{*}$ value of common vegetable oils.

Pinus halepensis seed oil showed some absorbance in the UV-C (100-290 nm) with a maximum of 2.39 units at $210 \mathrm{~nm}$ for oil diluted to $1: 800$, in the UV-B

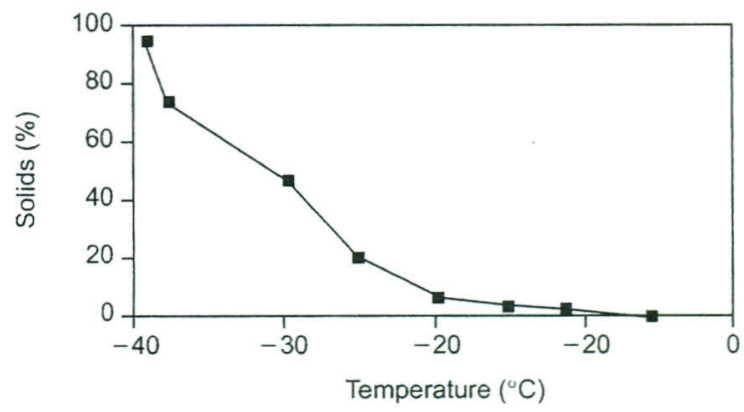

Figure 2. Solid-temperature curve for Aleppo pine seed oil determined by DSC. 
(290-320 nm) ranging from 0.3 to 0.1 for oil diluted to 1:100, and UV-A (320-400 nm) ranging from 0.1 to 0.02 for oil diluted to 1:100. Therefore, Aleppo pine seed oil may provide protection against both UV-A (an origin of oxidative stress to skin) and UV-B. The optical transmission of Pinus halepensis seed oil, especially in the UV range (290-400 nm) was comparable to that of date seed and raspberry seed oils. This is comparable to titanium dioxide preparations as a sun protection factor for UV-B (SPF) and a protection factor for UVA (PFA) (Besbes et al., 2004a; Oomah et al., 2000). Pinus halepensis seed oil also contained more yellow colouring than raspberry seed oil studied by Oomah et al. (2000). The latter is characterised by a lower absorbance than Aleppo pine seed oil (absorbance ranging from 0.08 to 0.11 against 0.17 to 0.19 at $440-460 \mathrm{~nm}$, respectively, for oils diluted to $1: 10$ ). This confirmed the results of colour measurements. Yellow colours, due partly to carotenoids, are beneficial, since they simulate the appearance of butter without the use of primary colorants, such as carotenes and annatos, commonly used in the oil and fat industry (Oomah et al., 2000).

\section{Oxidative Stability}

Oxidation is the main problem affecting oils, leading to aldehyde production which imparts strong disagreeable flavours and odours, referred to as rancidity. Generally, the rate of oxidation will depend on the degree of unsaturation of the oil and its temperature as well as the presence of antioxidants (McKevith, 2005). Oils deteriorate after an induction period in which relatively small changes occur (Gordon, 1991). Stability, although is not a standard parameter of quality, is useful to provide information about the hypothetical shelf-life of an oil (Aparicio et al., 1999).

Stability, expressed as the oxidation induction time, was about $24.5 \mathrm{~h}$ for Pinus halepensis seed oil (Table 5). This oxidation time is lower than that reported by Besbes et al. (2004a) for date seed oil (Deglet Nour cultivar). Such difference may be explained by the fact that Pinus halepensis seed oil contained more PUFA than date seed oil (Deglet Nour cultivar) (54.2 as against 14 , respectively). The latter also has a higher antioxidant content (phenolic compounds) (526 as against $186 \mu \mathrm{g} / \mathrm{g}$ for date seed and Pinus halepensis seed oils, respectively, Table 5) which mainly determines a greater resistance to auto-oxidation (Perrin, 1992: Tsimidou et al., 1992; Baldioli et al., 1996). Phenolics in vegetable oils may generally exert a beneficial effect on their oxidative stability (Farag et al., 2003). Aparicio et al. (1999) mentioned a significant correlation of phenols, oleic/linoleic ratio and tocopherols with oil stability, and it was also observed between total phenol content and oxidative stability by Rancimat (Gutfinger, 1981; Salvador et al., 2001). Phenolic
Table 5. Oxidation induction time and viscosity of seed oil from Pinus halepensis and Deglet Nour seed oils.

\begin{tabular}{lcc}
\hline & $\begin{array}{c}\text { Pinus halepensis } \\
\text { (mean } \pm \mathrm{SD}, \mathrm{n}=3 \text { ) }\end{array}$ & Deglet Nour $^{1}$ \\
\hline Induction time (h) & $24.4 \pm 2.5$ & 44.8 \\
Viscosity (mPa.s) & $7.17 \pm 0.05$ & 18.3 \\
\hline
\end{tabular}

'Besbes et al. (2004a).

compounds would contribute around $50 \%$ to the stability of olive oil, while the oleic/linoleic ratio would reach only $27 \%$. The contribution of total tocopherols and colouring pigments (chlorophylls and carotenoids) were around 9 and $13 \%$, respectively (Aparicio et al., 1999). The oxidative stability of other vegetable oils, such as canola, coconut, corn, grapeseed, olive, peanut, safflower, soybean and sunflower ranged from 6.1, $11.25,4.75,2.07,4.85,5.07,2.27,2.22$ and $3.25 \mathrm{~h}$, respectively at $110^{\circ} \mathrm{C}$ (Tan et al., 2002). This shows that Pinus halepensis seed oil oxidative stability was higher than that of most oleic-linoleic vegetable oils.

\section{Viscosity}

Viscosity of Pinus halepensis seed oil (Table 5) was lower than that reported by Besbes et al. (2004a) for date seed oil (Deglet Nour variety) $(7.17 \mathrm{mPa}$.s as against $18.3 \mathrm{mPa} . \mathrm{s}$ ), which may be explained by the fact that the latter contained less UFA (65.45 as against 82.6, for Deglet Nour and Pinus halepensis seed oils, respectively). It is worth noting that the viscosity of Pinus halepensis seed oil is lower than that of most vegetable oils ( $26 \mathrm{mPa} . \mathrm{s}, 47.3 \mathrm{mPa} . \mathrm{s}$ and $49.4 \mathrm{mPa} . \mathrm{s}$, for raspberry, safflower and grape seed oils, respectively (Oomah et al., 2000)). The viscosity of olive oil reported by Lalas and Tsakins (2002) varies from 45 to $80 \mathrm{mPa}$.s.

\section{Some Quality Parameters}

Pinus halepensis seed oil has a relatively higher phenol content (Table 6) compared to most edible oils except for olive oil, which is considered as a rich source of phenolic compounds in the Mediterranean diet. Salvador et al. (2001) reported that total phenolic content measured by the Folin-Ciocalteau method ranged from 19 to $380 \mathrm{mg} / \mathrm{kg}$, and from 124 to $516 \mathrm{mg} / \mathrm{kg}$ according to Nissiotis and Tasioula-Margari (2002). The amount of phenols in crude seed oils is an important factor when evaluating the quality of the oil because these compounds have been correlated with colour, the shelf-life of oil and, in particular, its resistance to oxidation (Cinquanta et al., 1997). Pinus halepensis seed oil could be considered as a potential source of natural phenolic compounds. Despite their 
Table 6. Physicochemical characterisation of Pinus halepensis seed oil.

\begin{tabular}{cc}
\hline Parameter & $\begin{array}{c}\text { Pinus halepensis } \\
\text { (mean } \pm \mathrm{SD}, \mathrm{n}=3 \text { ) }\end{array}$ \\
\hline Polyphenols (as mg gallic acid $/ \mathrm{kg}$ of oil) & $186 \pm 19$ \\
Chlorophyll $(\mathrm{mg} / \mathrm{kg})$ & $0.07 \pm 0.06$ \\
Refractive index $\left(\mathrm{at} 20^{\circ} \mathrm{C}\right)$ & $1.4750 \pm 0.0100$ \\
Acidity $(\%$ oleic acid) & $0.61 \pm 0.08$ \\
Saponification index $(\mathrm{mg} \mathrm{of} \mathrm{KOH} / \mathrm{g}$ of oil) & $190 \pm 13$ \\
lodine index $\left(\mathrm{g} \mathrm{of}_{2} / 100 \mathrm{~g}\right.$ of oil) & $117 \pm 10$ \\
Peroxide index (meq $\mathrm{O}_{2} / \mathrm{kg}$ of oil) & $3.18 \pm 0.05$ \\
$\epsilon_{232}$ & $0.51 \pm 0.01$ \\
$\epsilon_{270}$ & $1.5 \pm 0.31$ \\
\hline
\end{tabular}

participation in conferring specific flavour to oil (Caponio et al., 1999), dietary phenolic compounds might have a positive effect in the prevention of coronary heart disease and cancer (Owen et al., 2000; Tuck and Hayball, 2002) a protective and a therapeutic potential in oxidative damage-related pathologies (Auger et al., 2004).

The chlorophyll pigments (Table 6) are important quality parameters because they correlate with colour, which is a basic attribute for evaluating oil quality (Salvador et al., 2001). These pigments are involved in auto-oxidation and photo-oxidation mechanisms (Gutierrez et al., 1992; Mínguez-Mosquera et al., 1990). Interesse et al. (1971) reported that the oxidative stability of olive oil is greatly affected by the presence of chlorophylls and their derivatives, especially in the presence of light as they have the ability to transfer energy from light into chemical molecules. The chlorophyll content of Pinus halepensis seed oil is lower than that reported by Aparicio et al. (1999) for virgin olive oil $(0.07$ as against $9.32-12.67 \mu \mathrm{g} / \mathrm{g}$, respectively).

Refractive index of Aleppo pine seed oil (1.4750) was similar to that of olive oils studied by Lalas and Tsakins (2002) and date seed oils studied by Besbes et al. (2004b). The saponification value of 190 is comparable to Xylopia aethiopica oil (Barminas et al., 1999). The lower acidity of Pinus halepensis seed oil showed that it might be edible and could have a long shelf-life. It is known that the increase of free acidity is mainly due to enzyme activity (Boskow, 1996). The iodine index of 117 indicates that Pinus halepensis seed oil is a highly unsaturated oil and suggests that it contains high levels of oleic and linoleic acids, as previously shown in Table 3. The iodine value of Pinus halepensis seed oil is situated inside the interval range of the values mentioned by Tan et al. (2002) in some edible oils (9.37 to $145 \mathrm{~g}$ of $\mathrm{I}_{2} / 100 \mathrm{~g}$ oil). It provides a measure of degree of oil unsaturation and a means of predicting shelf-life. Lower iodine value means a more stable oil with a longer shelf-life. Peroxide value $\left(3.18 \mathrm{meq} \mathrm{O}_{2} / \mathrm{kg}\right.$ of oil) of Pinus halepensis seed oil is lower than that of canola $\left(6.68 \mathrm{meq} \mathrm{O}_{2} / \mathrm{kg}\right.$ of oil), grapeseed $(10.6 \mathrm{meq} / \mathrm{kg})$, olive
$(8.5 \mathrm{meq} / \mathrm{kg})$, peanut $(6.82 \mathrm{meq} / \mathrm{kg})$, safflower $(5.07 \mathrm{meq} / \mathrm{kg})$ and sunflower $(9.1 \mathrm{meq} / \mathrm{kg}$ ) oils (Tan et al., 2002). Salvador et al. (2001) reported that less than 5\% of the oils had a peroxide value higher than the upper limit of 20 established for the 'extra-virgin' olive oil

Aleppo pine seed oil showed low absorptivity values at 232 and $270 \mathrm{~nm}$, thus containing little amounts of primary (hydroperoxides) and secondary oxidation products. Compared to Nigella seed oil studied by Ramadan and Mörsel (2004), absorptivities at 232 and $270 \mathrm{~nm}$ of Pinus halepensis seed oil were relatively lower ( 0.51 and 1.5 as against 3.6 and 1.2 , respectively).

The results revealed that Aleppo pine (Pinus halepensis) seeds are a rich source of many important nutrients that appear to have a very positive effect on human health. The seed lipids of the investigated samples were rich in linoleic acid, which has a beneficial effect on blood lipids, lowering blood pressure and serum cholesterol. They constitute a good alternative source of essential fatty acids compared with common vegetable oils and could contribute to the overall dietary intake of the mineral elements studied. This unique fatty acid composition, relatively high polyphenol content and quality, and hence high protection against oxidative stress, relatively good shelf-life and other desirable physicochemical characteristics lead to more diverse and novel applications of Aleppo pine seed oil in the food, pharmaceutical, cosmetic and other non-food industries.

\section{ACKNOWLEDGEMENT}

The authors thank Mr. Mohamed Hammami for his valuable help in spectrometric and chromatographic analysis.

\section{REFERENCES}

AOAC (1990). Official Methods of Analyses. Washington, DC: Association of Official Analytical Chemists.

AOCS (1997). Official Methods and Recommended Practices of the American Oil Chemists' Society, 5th edn, Champaign, IL, US: AOCS Press.

Aparicio R., Roda L., Albi M.A. and Gutiérrez F. (1999). Effect of various compounds on virgin olive oil stability measured by Rancimat. Journal of Agricultural and Food Chemistry 47: 4150-4155.

Auger C., Al-Awadi N., Bornet A., Rouanet J.M., Gasc F., Cros G. and Teissedre P.L. (2004). Catechins and procyanidins in Mediterranean diets. Food Research International 37: 233-245.

Baldioli M., Servili M., Perretti G. and Montedoro G.F. (1996). Antioxidant activity of tocopherols and phenolic compounds of virgin olive oil. Journal of the American Oil Chemists Society 73: 1589-1593. 
Barminas J.T., James M.K. and Abubakar U.M. (1999). Chemical composition of seeds and oil of Xylopia aethiopica grown in Nigeria. Plant Foods for Human Nutrition, 53: 198-199.

Besbes S., Blecker C., Deroanne C., Drira N.E. and Attia H. (2004a). Date seeds: chemical composition and characteristic profiles of the lipid fraction. Food Chemistry 84: 577-584.

Besbes S., Blecker C., Deroanne C., Lognay G., Drira N.E. and Attia H. (2004b). Quality characteristics and oxidative stability of date seed oil during storage. Food Science and Technology International 10: 333-338.

Boskow D. (1996). Changes caused by enzymes and oxidation. In: Boskow D. (ed.), Olive Oil: Chemistry and Technology. Champaign, IL, US: AOCS Press, pp. 96-100.

Caponio F., Alloggio V. and Gomes T. (1999). Phenolic compounds of virgin olive oil: influence of paste preparation techniques. Food Chemistry 64: 203-209.

Cinquanta L., Esti M. and La Notte E. (1997). Evaluation of phenolic compounds in virgin olive oil during storage. Journal of the American Oil Chemists Society 74: $1259-1264$.

Deroanne C. (1977). L'analyse calorimétrique différentielle, son intérêt pratique pour le fractionnement de l'huile de palme et la détermination de la teneur en phase solide. Lebensmittel - Wissenschaft und Technologie 10: 251-255.

Eramus U. (1993). Fat content and fatty acid composition of seed oils. In: Erasmus U. Fats That Heal, Fats That Kill, Edmonton, Canada: revised edition. Alive Books.

Farag R.S., El-Baroty G.S. and Basuny A.M. (2003). The influence of phenolic extracts obtained from the olive plant (cvs. Picual and Kronakii), on the stability of sunflower oil. International Journal of Food Science and Technology 38: 81-87.

Gloria H. and Aguilera J.M. (1998). Assessment of the quality of heated oils by differential scanning calorimetry. Journal of Agricultural and Food Chemistry 46: $1363-1368$.

Gordon M.H. (1991). Oils and fats: taint or flavour? Chemistry in Britain 27: 1020-1022.

Greenfield H. and Southgate D.A.T. (1992). Food Composition Data. Production, Management and Use. London: Elsevier Applied Science.

Guilliams T.G. (2000). Fatty acids: essential therapeutic. The Standard 3: 1-8.

Gutfinger T. (1981). Polyphenols in olive virgin oils. Journal of American Oil Chemists Society 58: 966-968.

Gutierrez F., Garrido J., Gallardo L., Gandul B. and Minguez M.I. (1992). Action of chlorophylls on the stability of virgin olive oil. Journal of the American Oil Chemists Society 69: 866-871.

Halbault L., Barbé C., Aroztegui M. and De La Torre C. (1997). Oxidative stability of semi-solid excipient mixtures with corn oil and its implication in the degradation of vitamin A. International Journal of Pharmaceutics 147: 31-41.

Herrera M.L. and Anon M.C. (1991). Crystalline fraction- ation of hydrogenated sunflower seed oil: differential scanning calorimetry (DSC). Journal of the American Oil Chemists Society 68: 799-803.

Hsu S.Y. and Chung H.Y. (1998). Effects of processing factors on qualities of emulsified meatball. Journal of Food Engineering 36: 337-347.

Hsu S.Y. and Yu S.H. (2002). Comparisons on 11 plant oil fat substitutes for low-fat kung-wans. Journal of Food Engineering 51: 215-220.

Interesse F., Ruggiero S. and Vitagliano M, (1971). Autooxidation of olive oil: effects of chlorophyll pigments. Industrie Agrarie 9: 318-323.

International Union of Pure and Applied Chemistry (IUPAC) (1992). Paquot C. and Hautfenne A. (eds). Standard Method for the Analysis of Oils, Fats and Derivatives 7 th edn, London: Blackwell Scientific Publications.

Lalas S. and Tsakins J. (2002). Characterization of Moringa oleifera seed oil variety "Periyakulam 1". Journal of Food Composition and Analysis 15: 65-77.

Larrauri J.A., Rupérez P., Borroto B. and Saura-Calixto F. (1996). Mango peels as a new tropical fibre: preparation and characterisation. Lebensmittel - Wissenschaft und Technologie 29: 729-733.

Le Thiec D. and Manninen S. (2003). Ozone and water deficit reduced growth of Aleppo pine seedlings. Plant Physiology and Biochemistry 41: 55-63.

Maestre F.T., Cortina J., Bautista S. and Bellot J. (2003). Does Pinus halepensis facilitate the establishment of shrubs in Mediterranean semi-arid afforestations?. Forest Ecology and Management 176: 147-160.

McKevith B. (2005). Nutritional aspects of oilseeds. British Nutrition Foundation 30: 13-26.

Mínguez-Mosquera M.I., Gandul B. and Garrido J. (1990). Pigments present in virgin olive oil. Journal of the American Oil Chemists Society 67: 192-196.

Mínguez M.I., Rejano L., Gandul B., Higinio A. and Garrido J. (1991). Color pigments correlation in virgin olive oil. Journal of American Oil Chemists Society 68: 669-671.

Nahal I. (1985) Le pin d'Alep et le pin brutia dans la sylviculture méditerranéenne. Options Méditerranéennes: Série Etudes, n. 1986-I. Paris: CIHEAM, pp. 1-9.

Nasri N. and Triki S. (2004). Lipid analysis of Tunisian pine seeds: $P$. halepensis Mill. and P. pinea L. La Rivista Italiana Delle Sostanze Grasse 4: 244-247.

Nasri N., Khaldi A., Fady B. and Triki S. (2005). Fatty acids from seeds of Pinus pinea L.: composition and population profiling. Phytochemistry $66: 1729-1735$.

Nergiz C. and Dönmez I. (2004). Chemical composition and nutritive value of Pinus pinea L. seeds. Food Chemistry 86: 365-368.

Nissiotis M. and Tasioula-Margari M. (2002). Changes in antioxidant concentration of virgin olive oil during thermal oxidation. Food Chemistry 77: 371-376.

Oomah B.D., Ladet S., Godfrey D.V., Liang J. and Girard B. (2000). Characteristics of raspberry (Rubus idaeus L.) seed oil. Food Chemistry 69: 187-193. 
Owen R.W., Giacosa A., Hull W.E., Haubner R., Spiegelhalder B. and Bartsh H. (2000). The antioxidant/anticancer potential of phenolic compounds isolated from olive oil. European Journal of Cancer 36: 1235-1247.

Perrin J.L. (1992). Les composés mineurs et les antioxygènes naturels de l'olive et de son huile. Revue Francaise des Corps Gras 39: 25-32.

Raeda C. and Arianoutsou M. (2000). Cellulose decomposition rates and soil arthropod community in a Pinus halepensis Mill. forest of Greece after a wildfire. European Journal of Soil Biology 36: 57-64.

Ramadan M.F. and Mörsel J.-T. (2004). Oxidative stability of black cumin (Nigella sativa L.), coriander (Coriandrum sativum L.) and niger (Guizotia abyssinca Cass.) crude seed oils upon stripping. Europeen Journal Lipid Science and. Technology 106: 35-43.

Sagrero-Nieves L. (1992). Fatty acid composition of Mexican pine nut (Pinus cembroides) oil from three seed coat phenotypes. Journal of the Sciences of Food Agriculture 59: 413-414.

Salvador M.D., Aranda F., Gómez-Alonso S. and Fregapane G. (2001). Cornicabra virgin olive oil: a study of five crop seasons. Composition, quality and oxidative stability. Food Chemistry 74: 267-274.
Tan C.P., Che Man Y.B., Selamat J. and Yusoff M.S.A. (2002). Comparative studies of oxidative stability of edible oils by differential scanning calorimetry and oxidative stability index methods. Food Chemistry 76: 385-389.

Thompson R.L., Pyke S., Scott E.A., Thompson S.G. and Wood D.A. (1993). Cigarette smoking, polyunsaturated fats and coronary heart disease. American. New York Academy. Science 686: 130-138.

Tsimidou M., Papadopoulos G. and Boskou D. (1992). Phenolic compounds and stability of virgin olive oil Part I. Food Chemisty 45: 141-144.

Tuck K.L. and Hayball P.J. (2002). Major phenolic compounds in olive oil: metabolism and health effects. Journal of Nutritional Biochemistry 13: 636-644.

Wolff R.L. and Bayard C.C. (1995). Fatty acid composition of some pine seed oil. Journal of the American Oil Chemists Society 72: 1043-1046.

Wolff R.L. and Marpeau A.M. (1997). $\Delta 5$-olefinic acids in the edible seeds of nut pines (Pinus cembroides edulis) from the United States. Journal of the American Oil Chemists Society 74: 613-614. 